\title{
KEPASTIAN HUKUM SISTEM PUBLIKASI DALAM PENDAFTARAN TANAH DI INDONESIA MENURUT UU RI NOMOR 5 TAHUN 1960 TENTANG POKOK-POKOK AGRARIA
}

\author{
I Dewa Ayu Widyani ${ }^{1}$
}

\begin{abstract}
The purposes of this paper is in order to know about the publication system in enrolling the land that be followed by Indonesia and the form of law protection that can be given to the holder of right. From the description of the writing can be concluded whereas the publication system in enrolling the land is the negative system that contain of positive element. In solving about the weakness of this publication system, so be decided in PP24/1997 Article 32 point (2) namely in the matter about the land that have been issued its certificate on behalf of someone or the law institution that getting it by the good willingness and factually master it, so that the other party who feel have an authority of such land, cannot claim again about the implementation of it right. If in term of time about five (5) years during be issued the certificate do not applied the objection.
\end{abstract}

\section{Kata kunci : Kepastian hukum, sistem publikasi, pendaftaran tanah}

\section{Pendahaluan}

Pendaftaran tanah merupakan suatu proses bagaimana kepemilikan (hak atas tanah) tersebut kemudian lahir. Tanpa melalui proses tersebut tidak akan mungkin seseorang memiliki alas hak yang kuat atas tanahnya.

Begitu pentingnya pendaftaran tanah di Indonesia, sehingga kemudian Undang-Undang Nomor 5 Tahun 1960 tentang Peraturan Dasar Pokok-pokok Agraria yang kemudian terkenal di masyarakat dengan sebutan UUPA (Undang-Undang Pokok Agraria) melalui Pasal 19 memerintahkan kepada pemerintah untuk melakukan pendaftaran tanah di seluruh wilayah Indonesia, untuk menjamin kepastian hukum bagi pemiliknya. Ketentuan Pasal 19 ini lebih lanjut dilaksanakan dengan Peraturan Pemerintah Nomor 10 Tahun 1961 tentang Pendaftaran Tanah (PP10/1961), yang selanjutnya digantikan dengan Peraturan

Pemerintah Nomor 24 Tahun 1997 tentang Pendaftaran Tanah (PP24/1997) sebagai revisi atas PP10/1961.

Peraturan tersebut di atas merupakan bentuk pelaksanaan pendaftaran tanah dalam rangka rechts kadaster (pendaftaran tanah) yang tujuannya memberikan kepastian hukum dan perlindungan hukum kepada pemegang hak atas tanah sehingga menimbulkan

${ }^{1}$ Dosen tetap FH UKI rasa aman dan rasa mantap mengenai kepastian hukumnya, kepastian mengenai tanah yang di-haki-nya serta adanya perlindungan hukum untuk mencegah gangguan dari penguasaan pihak lainnya.

Penerapan sistem publikasi pendaftaran tanah di suatu negara pada dasarnya sesuai dengan asas hukum yang dianut oleh negara yang bersangkutan. Dalam rangka peralihan hak atas tanah dikenal beberapa asas, antara lain, asas itikad baik, dimana dengan asas ini orang yang memperoleh suatu hak dengan itikad baik akan tetapi menjadi pemegang hak yang sah menurut hukum ${ }^{2}$, sedangkan asas nemoplus yuris dapat diartikan bahwa orang tidak dapat mengalihkan hak melebihi hak yang ada padanya. ${ }^{3}$ Sistem publikasi yang diterapkan dalam asas itikad baik adalah sistem publikasi positif sedangkan asas nemolus yuris menggunakan sistem publikasi negatif. Pada dasarnya di dunia ini tidak ada satu negara pun yang menganut salah satu asas tersebut secara murni, karena masingmasing asas ini memiliki kelebihan dan kekurangan.

Sistem publikasi pendaftaran tanah positif, ditemukan di negara-negara jajahannya. Sementara sistem publikasi pendaftaran tanah negatif berlaku di negara-negara Eropa Kontinental seperti Belanda dan Indonesia.

\footnotetext{
${ }^{2}$ Adrian Sutedi, Peralihan Hak Atas Tanah dan Pendaftarannya, Cet. 4, Jakarta: Sinar Grafika, 2010, h. 117

${ }^{3}$ Ibid $\mathrm{h} 118$
} 


\section{Permasalahan:}

Memahami hal tersebut maka permasalahan dalam tulisan ini adalah bagaimana sistem publikasi dalam pendaftaran tanah di UUPA memberikan kepastian hukum?

\section{Tujuan Penulisan}

Untuk mengetahui sistem publikasi dalam pendaftaran tanah di dalam Undang-Undang RI No 5 tahun 1960 dapat memberi kepastian hukum.

\section{Pengertian serta Asas-asas dalam Pendaftaran Tanah}

Pada tanggal 24 September 1960 berlaku Undang-Undang Nomor 5 Tahun 1960 Tentang Peraturan Dasar Pokok-Pokok Agraria, LNRI Tahun 1960 No. 104-TLNRI No. 2043. Undang-Undang ini lebih dikenal dengan sebutan Undang-Undang Pokok Agraria (UUPA). Dengan diundangkannya UUPA, maka terciptalah hukum agraria yang bersifat nasional, dengan mencabut peraturan-peraturan dan keputusan yang dibuat pada masa pemerintahan Hindia Belanda antara lain Agrarischecuet Stb.1870 No. 55 dan Agrarische Besluit Stb.1870 No. 118.

Salah satu tujuan diundangkannya UUPA sebagaimana dimuat dalam Penjelasan Umumnya adalah untuk memberikan kepastian hukum mengenai hakhak atas tanah bagi rakyat seluruhnya melalui tersedianya perangkat hukum yang tertulis, lengkap dan jelas yang dilaksanakan secara konsisten sesuai dengan jiwa dan ketentuan-ketentuannya sertapenyelenggaraan pendaftaran tanah yang memungkinkan bagi pemegang hak atas tanah untuk dengan mudah membuktikan hak atas tanah yang dikuasainya, dan bagi pihak yang berkepentingan.

Seperti calon pembeli dan calon kreditur, untuk memperoleh keterangan yang diperlukan mengenai tanah yang menjadi objek perbuatan hukum yang akan dilakukan, serta bagi pemerintah untuk melaksanakan kebijaksanaan pertanahan.

Pendaftaran tanah yang bertujuan memberikan jaminan kepastian hukum, diwujudkan melalui kepastian status hak yang didaftar, kepastian subjek hak, kepastian objek hak, pendaftaran ini menghasilkan sertifikat sebagai tanda bukti hak-haknya. ${ }^{4}$

Pengertian pendaftaran tanah dimuat dalam $\mathrm{Pa}-$ sal 1 angka 1 Peraturan Pemerintah Nomor 24 Tahun 1997 Tentang Pendaftaran Tanah yaitu serangkaian

\footnotetext{
${ }^{4}$ Urip Santoso, Hukum Agraria Kajian Komprehensif, Jakarta Kencana, 2012, h.. 278.
}

kegiatan yang dilakukan oleh pemerintah secara terus menerus, berkesinambungan dan teratur, meliputi pengumpulan, pengolahan, pembukuan dan penyajian serta pemeliharaan data fisik dan data yuridis, dalam bentuk peta dan daftar, mengenai bidang-bidang tanah dan satuan-satuan rumah susun, termasuk pemberian surat tanda bukti haknya bagi bidangbidang tanah yang sudah ada haknya dan hak milik atas satuan rumah susun serta hak-hak tertentu yang membebaninya.

Dari pengertian tersebut dapat diuraikan unsurunsurnya yaitu:

\section{a. Adanya serangkaian kegiatan}

Ini menunjukan bahwa dalam pendaftaran tanah terdapat beberapa ke giatan yang berkaitan satu dengan yang lainnya, berurutan, menjadi satu kesatuan rangkaian yang bermuara pada tersedianya data yang diperlukan dalam rangka memberikan jaminan kepastian hukum di bidang pertanahan.

Kegiatan pendaftaran tanah dapat berupa kegiatan pendaftaran tanah untuk pertama kali yaitu apabila tanah yang bersangkutan sama sekali belum pernah didaftarkan. Kegiatan ini dapat dilakukan dengan cara pendaftaran secara sistematik yaitu pendaftaran dilakukan secara serentak yang meliputi semua objek pendaftaran tanah yang belum didaftar dalam wilayah atau bagian wilayah suatu desa/kelurahan. Pendaftaran ini diprakarsai oleh pemerintah berdasarkan suatu rencana kerja jangka panjang dan tahunan serta dilaksanakan di wilayah-wilayah yang ditetapkan oleh Menteri Negara Agraria/Kepala Badan Perta-nahan Nasional.

Pendaftaran tanah untuk pertama kali dapat juga dilakukan dengan sistem pendaftaran tanah secara sporadik yaitu pendaftaran tanah yang dilaksanakan atas permintaan pihak yang berkepentingan mengenai satu atau beberapa objek pendaftaran tanah dalam wilayah atau bagian wilayah suatu desa/kelurahan secara individual atau massal.

Kegiatan pendaftaran tanah pertama kali, meliputi:

1. Pengumpulan dan pengolahan data fisik

2. Pembuktian hak dan pembukuannya

3. Penerbitan sertifikat

4. Penyajian data fisik dan data yuridis

5. Penyimpanan daftar umum dan dokumen

\section{b. Dilakukan oleh Pemerintah}

Instansi pemerintah yang menyelenggarakan pendaftaran tanah adalah Badan Pertanahan Nasional (BPN), dan dalam pelaksanaannya dilakukan oleh Kepala Kantor Pertanahan Kabupaten/Kota. 


\section{c. Secara terus menerus dan berkesinambungan}

Ini menunjukan bahwa pelaksanaan kegiatan yang sekali dimulai tidak akan ada akhirnya. data yang sudah terkumpul dan tersedia harus selalu dipelihara, dalam arti disesuaikan dengan perubahan yang terjadi kemudian hingga tetap sesuai dengan keadaan yang terakhir. ${ }^{5}$

\section{d. Secara teratur}

Bahwa semua kegiatan harus berdasarkan/berlandaskan peraturan perundang-undangan yang sesuai, hasil dari pendaftaran akan merupakan data bukti menurut hukum, meskipun kekuatan pembuktiannya antara negara satu dengan lainnya berbeda-beda. ${ }^{6}$

\section{e. Bidang-bidang tanah dan satuan rumah susun}

Kegiatan pendaftaran tanah dilakukan terhadap Hak Milik,HakGunaUsaha,HakGunaBangunan,HakPakai, Hak Pengelolaan, Tanah Wakaf, Hak Milik Atas Satuan Rumah Susun, Hak Tanggungan dan Tanah Negara.

\section{f. Pemberian Surat Tanda Bukti Hak}

Hasil dari pendaftaran tanah adalah surat tanda bukti hak berupa sertifikat atas sebidang tanah yang sudah ada haknya dan sertifikat hak milik atas satuan rumah susun, hak tanggungan dan tanah negara.

Sertifikat menurut PP24/1997 Tentang Pendaftaran Tanah merpakan surat tanda bukti yang berfungsi sebagai alat pembuktian yang kuat mengenai data fisik dan data yuridis yang termuat di dalamnya. Data fisik yaitu data mengenai letak, batas dan luas tanah yang bersangkutan, kemudian data yuridis adalah data mengenai status hukum tanah, pemilik tanah dan hak-hak apa saja yang membebani tanah tersebut.

Sertifikat hak atas tanah terdiri dari salinan buku tanah dan surat ukur yang asli dijahit menjadi satu dan diberi sampul. Buku tanah yang asli digunakan untuk arsip di Kantor Pertanahan Seksi Pendaftaran Tanah, sedangkan salinannya diberikan kepada pemegang haknya. Jika terjadi pencatatan pada buku tanah, selalu dilakukan bersama-sama, baik yang ada pada arsip maupun salinan.

\section{g. Hak tertentu yang membebani}

Dalam pendaftaran, objek pendaftaran, kadangkala sedang dibebani oleh hak lainnya, seperti hak milik dibebani hak tanggungan dan seterusnya.

\section{Asas-asas Pendaftaran Tanah}

Menurut Sudikno Mertokusumo, azas-azas dalam Pendaftaran Tanah terdapat 2 (dua) asas ${ }^{7}$ :

\footnotetext{
${ }^{5}$ Mhd Yamin Lubis dan Abd Rahim Lubis, Hukum Pendaftaran Tanah, Bandung: Mandar Maju, 2008, h. 73.

${ }^{6}$ Ibid, h. 73

${ }^{7}$ Sudikno Mertokusumo, Hukum dan Politik Agraria,Jakarta : Universitas Terbuka, Karunika, Jakarta, 1988, h. 99
}

\section{a. Asas Specialiteit}

Pelaksanaan pendaftaran tanah itu diselenggarakan atas dasar peraturan perundang-undangan tertentu, yang secara teknis menyangkut masalah pengukuran, pemetaan, dan pendaftaran peralihannya. Oleh karena itu, dalam pelaksanaan pendaftaran tanah dapat memberikan kepastian hukum terhadap hak atas tanah, yaitu memberikan data fisik yang jelas mengenai luas tanah, letak, dan batas-batas tanah.

\section{b. Asas Openbaarheid (Asas Publisitas)}

Asas ini memberikan data yuridis tentangn siapa yang menjadi subjek haknya, apa nama hak atas tanah, serta bagaimana terjadinya peralihan dan pembebanannya. Data ini sifatnya terbuka untuk umum, artinya setiap orang dapat melihatnya.

Dalam pendaftaran tanah terdapat asas yang harus menjadi patokan dasar dalam melakukan pendaftaran tanah, sebagaimana diatur dalam Pasal 2 PP24/1997, bahwa pendaftaran tanah dilakukan berdasarkan asas:

a. Asas Sederhana

Asas ini dimaksudkan agar ketentuan-ketentuan pokoknya maupun prosedurnya dengan mudah dapat dipahami oleh pihak-pihak yang berkepentingan, terutama para pemegang hak atas tanah.

b. Asas Aman

Asas ini untuk menunjukan bahwa pendaftaran tanah perlu diselenggarakan dengan teliti dan cermat, sehingga hasilnya dapat memberikan jaminan kepastian hukum sesuai dengan tujuannya.

c. Asas Terjangkau

Asas ini dimaksudkan keterjangkauan bagi pihakpihak yang memerlukan, khususnya dengan memperhatikan kebutuhan dan kemampuan golongan ekonomi lemah. Pelayanan yang diberikan dalam rangka penyelenggaraan pendaftaran tanah harus bisa terjangkau oleh pihak yang memerlukan.

\section{d. Azas Mutakhir}

Asas ini menghendaki kelengkapan yang memadai dalam pelaksanaan dan berkesinambungan dalam pemeliharaan datanya. Data yang tersedia harus menunjukan keadaan yang mutakhir. Untuk itu diikuti kewajiban mendaftar dan pencatatan perubahan-perubahan yang terjadi. Azas ini menuntut dipeliharanya data pendaftaran tanah secara terus menerus dan berkesinambungan, sehingga data yang tersimpan di Kantor Pertanahan selalu sesuai dengan keadaan nyata di lapangan.

e. Azas Terbuka

Azas ini dimaksudkan agar masyarakat dapat mengetahui atau memperoleh keterangan mengenai data fisik dan data yuridis yang benar setiap saat di Kantor Pertanahan Kabupaten/Kota. 


\section{Sistem Publikasi Dalam Pendaftaran Tanah}

Penyelenggaraan pendaftaran tanah, memberikan surat tanda bukti hak bagi seseorang. Dengan demikian pemegang hak atas tanah dengan mudah dapat membuktikan penguasaan terhadap tanah tersebut. Dengan azas terbuka yang dianut dalam pendaftaran tanah, memungkinkan calon pembeli maupun kreditur untuk melihat maupun memperoleh keterangan yang diperlukan sebelum melakukan suatu perbuatan hukum.

Dalam pendaftaran tanah sering timbul masalah bagaimana hukum memberi perlindungan kepada mereka yang melakukan perbuatan hukum berdasark an data yang disajikan jika kemudian terbukti data itu tidak benar. Dalam hal ini sangat tergantung dari sistem publikasi dalam pendaftaran tanah yang digunakannya.

Sistem publikasi dalam pendaftaran tanah dibagi atas sistem positif dan sistem negatif.

\section{Sistem Publikasi Positif}

Menurut Effendi Perangin sebagaimana dikutip oleh Urip Santoso, sistem publikasi positif mengandung pengertian apa yang terkandung dalam buku tanah dan surat-surat tanda bukti hak yang dikeluarkan merupakan alat pembuktian yang mutlak, sehingga pihak ketiga yang bertindak atas bukti-bukti tersebut mendapatkan perlindungan yang mutlak, meskipun dikemudian hari terbukti bahwa keterangan yang terdapat didalamnya tidak benar. Mereka yang dirugikan akan mendapat kompensasi dalam bentuk lain ${ }^{8}$. Demikian juga Arie S Hutagalung mengatakan bahwa orang yang mendaftar sebagai pemegang hak atas tanah tidak dapat diganggu gugat lagi haknya dan negara sebagai pendaftar menjamin bahwa pendaftaran yang dilakukan adalah benar. ${ }^{9}$

Ciri-ciri pendaftaran tanah yang mempergunakan sistem publikasi positif, yaitu pejabat pelaksana bersikap aktif dan yang dicari adalah kebenaran materiil.

a. Instansi penyelenggara tidak cuma menerima begitu saja keterangan tentang hak ataupun status tanah yang terdaftar, tetapi akan meneliti satu per satu secara cermat dan mendalam.

b. Seandainya terjadi kekeliruan, dan meskipun ada keputusan hakim, keterangan dalam tanda bukti hak tetap tidak dapat diubah pihak yang dirugikan akan memperoleh ganti rugi dari pemerintah sejumlah harga tanah yang diambil dari premi asuransi tanah tersebut, karena pemerintah yang

\footnotetext{
${ }^{8}$ Urip Santoso, Pendaftaran dan Peralihan Hak Atas Tanah. Cet. 2, Jakarta: Kencana, 2010, h. 263.

${ }^{9}$ Ibid h. 263-264
}

bertanggung jawab atas kesalahan petugasnya. Dengan demikian, orang yang seharusnya berhak menjadi tidak berhak.

c. Memberi perlindungan yang mutlak, baik terhadap pemegang haknya maupun terhadap pihak ketiga karena keterangan yang tercantum dalam tanda bukti hak tidak dapat dilaksanakan perubahan.

d. Hasil pendaftaran memberikan alat pembuktian yang mutlak sifatnya dan tidak dapat diganggu gugat.

Ciri-ciri sistem publikasi positif tersebut di atas terlihat kelebihan atau sebaliknya kekurangan dari sistem tersebut antara lain:

a. Pejabat pendaftaran tanah bersikap aktif

b. Sehingga kebenaran dalam tanda bukti hak bersifat mutlak

c. Dengan demikian memberikan jaminan kepastian hukum bagi pemegang haknya.

Namun kelebihan ini juga dapat merupakan kelemahan dalam sisten ini yaitu:

a. Pemilik tanah yang sesungguhnya akan kehilangan haknya, akibat tanah tersebut telah disertifikatkan atas nama pihak lain yang tidak dapat dirubah lagi.

b. Dengan peran aktif pejabat pendaftaran tanah, membutukan waktu yang lebih lama dan prasarana yang mahal.

c. Keputusan pengadilan tidak akan dapat merubah keadaan

\section{Sistem Publikasi Negatif}

Sistem ini dipergunakan untuk melindungi pemegang hak yang sebenarnya, sehingga pemegang hak tersebut akan selalu dapat menuntut kembali haknya meskipun sudah terdaftar atas nama orang lain. Dalam sistem publikasi negatif negara hanya secara pasif menerima apa yang dinyatakan oleh pihak yang akan mendaftarkan tanahnya, sehingga setiap saat dapat digugat oleh pihak yang merasa lebih berhak atas tanah tersebut.

Dengan demikian ciri-ciri pendaftaran tanah dengan sistem publikasi negatif antara lain yaitu pejabat pelaksana pendaftaran bersikap pasif, yang dicari adalah kebenaran formal:

a. Instansi penyelenggara cukup menerima keterangan hak yang didaftar sebagaimana adanya, tanpa dilakukan penelitian secara mendalam.

b. Bilamana terjadi kesalahan dalam pencatatan, berdasarkan putusan hakim dapat diperbaiki oleh petugas penyelenggara pendaftaran tanah. Den- 
gan demikian orang yang berhak akan tetap terlindungi.

c. Hanya memberi perlindungan terhadap pemegang haknya saja. Sehingga berlaku azas "nemo plus juris" bahwa orang tidak dapat bertindak melebihi kewenangan yang ada padanya, siapa yang namanya tercantum dalam tanda bukti hak tersebut maka dialah pemegang haknya.

Dengan ciri tersebut, maka sistem publikasi negatif dalam pendaftaran juga mempunyai kelebihan yaitu:

a. Pemegang hak yang sesungguhnya terlindungi haknya dari pihak lain yang tidak berhak.

b. Tidak ada batas waktu bagi pemilik tanah sesungguhnya untuk menuntut haknya yang telah disertifikatkan oleh pihak lain.

Dengan demikian kelemahannya adalah:

a. Tidak ada kepastian atas keabsahan sertifikat, karena setiap saat dapat atau mungkin digugat dan dibatalkan jika terbukti tidak sah penerbitannya.

b. Peran pejabat pendaftaran tanah yang pasif tidak mendukung keakuratan dan kebenaran data yang tercantum didalam sertifikat.

Di dalam praktik, kedua sistem ini tidak pernah digunakan secara murni, karena dengan sistem positif misalnya, akan memberi beban terlalu berat kepada negara sebagai pendaftar. Apabila ada kesalahan dalam pendaftaran, negara harus menanggung akibat dari kesalahan tersebut. Di samping itu penelitian yang dilakukan secara cermat, mengakibatkan lambannya proses pendaftaran. Oleh karena semua risiko yang diakibatkannya begitu besar, maka negara biasanya mengenakan biaya yang mahal untuk persiapan menghadapi tuntutan ganti rugi jika terjadi kesalahan pejabat dalam melaksanakan pendaftaran.

\section{Sistem Publikasi Dalam Pendaftaran Tanah di Indonesia}

Untuk memahami sistem publikasi dalam pendaftaran tanah yang berlaku di Indonesia, maka harus dilihat ketentuan-ketentuan yang mengatur tentang pendaftaran tanah.

Berdasarkan ketentuan Pasal 19 Ayat (2) UUPA menyebutkan bahwa pendaftaran tanah meliputi pemberian surat-surat tanda bukti hak yang berlaku sebagai alat pembuktian yang "kuat". Kata "kuat" yang digunakan menjelaskan kekuatan alat bukti yang dihasilkan oleh kegiatan pendaftaran tanah.

Hal tersebut menunjukan bahwa sistem publikasi dalam pendaftaran tanah yang digunakan bukan sistem positif, karena dalam sistem publikasi positif, alat bukti yang dihasilkan mempunyai sifat "mutlak", begitu sebaliknya dengan menyatakan alat bukti tersebut sebagai alat bukti yang "kuat" ini menunjukan bukan sistem negatif yang murni. Begitu juga kalau dilihat bahwa secara tegas bahwa pendaftaran tanah diselenggarakan oleh pemerintah untuk menjamin kepastian hukum (Pasal 19 Ayat (1) UUPA).

Pasal 23, Pasal 32 dan Pasal 38 UUPA menyatakan bahwa pendaftaran merupakan alat pembuktian yang kuat untuk peristiwa hukum dan perbua$\tan$ hukum tertentu mengenai tanah. Selanjutnya PP10/1961 tentang pendaftaran tanah yang direvisi dengan PP24/1997 Tentang Pendaftaran tanah, mengatur ketentuan-ketentuan sebagaimana dalam Pasal 32 Ayat (1) yang menyatakan:

"Sertifikat merupakan surat tanda bukti hak yang berlaku sebagai alat pembuktian yang kuat mengenai data fisik dan data yuridis yang termuat didalamnya, sepanjang data fisik dan data yuridis tersebut sesuai dengan data yang ada dalam ukur dan buku tanah hak yang bersangkutan."

Dalam Penjelasan Umumnya dijelaskan bahwa dalam rangka memberikan kepastian hukum kepada para pemegang hak atas ntanah, diberikan penegasan mengenai bagaimana kekuatan pembuktian yang kuat oleh UUPA. Selanjutnya menurut peraturan pemerintah ini bahwa dinyatakan selama belum dibuktikan yang sebaliknya, data fisik dan data yuridis yang dicantumkan dalam sertifikat harus diterima sebagai data yang benar, baik dalam perbuatan hukum seharihari maupun dalam sengketa di pengadilan.

Dengan melihat penjelasan tersebut di atas maka dapat dikatakan sistem publikasi yang dianut di Indonesia tidak secara umum menganut sistem positif atau negatif, karena itu Indonesia menganut sistem publikasi negatif yang mengandung unsur-unsur positif. ${ }^{10}$

Untuk mengatasi kelemahan sistem negatif yang dianut, maka ditegaskan kemudian dalam Pasal 24/1997 Pasal 32 Ayat (2) yang menyebutkan:

"Dalam hal atas suatu bidang tanah sudah diterbitkan sertifikat atas nama orang atau badan hukum yang memperoleh tanah tersebut dengan itikad baik dan secara nyata menguasainya, maka pihak lain yang merasa mempunyai hak atas tanah tersebut, tidak dapat lagi menuntut pelaksanaan hak tersebut, apabila dalam waktu 5 (lima) tahun sejak diterbitkannya sertifikat itu tidak mengaju-

\footnotetext{
${ }^{10}$ Boedi Harsono, Hukum Agraria Indonesia: Sejarah Pembentukan Undang-Undang Pokok Agraria, Isi dan Pelaksanaannya. Cet. 10. Jakarta: Djambatan, 2005, h. 477.
} 
kan keberatan secara tertulis kepada pemegang sertifikat dan kepada Kantor Pertanahan yang bersangkutan ataupun tidak mengajukan gugatan ke Pengadilan mengenai penguasaan tanah atau penerbitan sertifikat tersebut."

Penjelasan Pasal 32 Ayat (2) bahwa di dalam hukum tanah (Agraria)di Indonesia tidak mengenal lembaga tersebut di atas (lembaga acquicitieve verjaring), mengingat dasar dari hukum tanah (Agraria) adalah hukum adat. Tapi didalam hukum adat dikenal suatu lembaga yang dapat digunakan untuk mengatasi kelemahan sistem publikasi negatif dalam pendaftaran tanah yaitu disebut lembaga "rechtsverwerking". Lembaga ini dapat dijelaskan bahwa dalam hukum adat, jika seseorang dalam waktu yang lama telah membiarkan tanahnya (diterlantarkan) tidak dikerjakan, kemudian tanah tersebut dikerjakan oleh orang lain yang memperolehnya dengan itikad baik, maka yang bersangkutan akan hilang haknya untuk menuntut kembali tanah tersebut.

Hal ini sesuai dengan ketentuan yang diatur dalam UUPA Pasal 27, Pasal 34 dan Pasal 40. Hal ini menunjukan bahwa lembaga yang ada dalam hukum adat sebenarnya merupakan bagian dari hukum tanah nasional, mengingat dasar dari UUPA adalah hukum adat sehingga hal ini merupakan wujud konkrit dalam penerapan ketentuan UUPA mengenai tanah-tanah yang diterlantarkan.

\section{Kesimpulan}

1. Sistem publikasi yang dianut oleh UUPA (di Indonesia), tidak menganut sistem publikasi yang murni, akan tetapi menganut sistem publikasi negatif yang mengandung unsur-unsur positif.

2. Untuk memberikan kepastian hukum bagi pemegang hak atas tanah, ditegaskan bahwa sertifikat merupakan alat pembuktian yang kuat, selama belum ada yang membuktikan sebaliknya, maka data fisik dan data yuridis yang dicantumkan dalam sertifikat harus diterima sebagai data yang benar, baik dalam perbuatan hukum sehari-hari, maupun dalam sengketa di Pengadilan.

3. Untuk mengatasi kelemahan sistem negatif, maka melalui Pasal 32 (2) PP24/1997 dinyatakan dalam hal suatu bidang tanah sudah diterbitkan atas nama orang atau badan hukum yang memperoleh tanah tersebut dengan itikad baik dan secara nyata menguasainya, maka pihak lain yang merasa mempunyai tanah tersebut tidak dapat lagi menuntut pelaksanaan haknya apabila dalam waktu
5 (lima) tahun sejak diterbitkannya sertifikat tersebut, tidak mengajukan keberatan secara tertulis kepada pemegang sertifikat dan kepada kantor pertanahan yang bersangkutan, atau tidak mengajukan gugatan ke pengadilan mengenai penguasaan tanah atau penerbitan sertifikat tersebut.

\section{Saran}

1. Pemerintah harus segera mengantisipasi sistem publikasi dalam pendaftaran tanah atau memberlakukan sistem yang lebih menjamin kepastian hukum lagi pemegang hak atas tanah.

2. Pemerintah harus secara gencar mensosialisasikan tentang sistem publikasi untuk mencegah pihak-pihak yang berhak atas tanah tertentu menjadi kehilangan haknya dengan adanya ketentuan Pasal 32 ayat (2) PP24/1997.

3. Disarankan kepada pihak yang ingin melakukan pendaftaran tanah, hendaknya pendaftaran dilakukan dengan itikad baik, karena secara nyata menguasai tanah.

\section{Daftar Pustaka}

\section{Buku}

Adrian Sutedi, Peralihan Hak atas Tanah dan Pendaftarannya. Cet. 4, Jakarta: Sinar Grafika, 2010.

Abd. Rahim Lubis dan Mhd Yamin Lubis, Hukum Pendaftaran Tanah, Bandung: Mandar Maju, 2008.

Boedi Harsono, Hukum Agraria Indonesia: Sejarah Pembentukan Undang-Undang Pokok Agraria, Isi dan Pelaksanaannya. Cet. 10, Jakarta: Djambatan, 2005.

Sudikno Mertokusumo, Hukum dan Politik Agraria, Jakarta: Universitas Terbuka, Karunika, 1988.

Urip Santoso, Hukum Agraria Kajian Komprehensif, Jakarta: Kencana, 2012.

\section{Peraturan Perundang-undangan}

Undang-Undang Nomor 5 Tahun 1960 Tentang Peraturan Dasar Pokok-Pokok Agraria

Peraturan Pemerintah Nomor 10 Tahun 1961 Tentang Pendaftaran Tanah.

Peraturan Pemerintah Nomor 24 Tahun 1997 Tentang Pendaftaran Tanah. 